\title{
Historians or History Teachers? A Qualitative Study in Pedagogical Formation Program in Turkey
}

\author{
Ali Ünişen \\ Correspondence: Ali Ünişen, Department of Educational Sciences, Faculty of Education, Adiyaman University, \\ Adiyaman, Turkey.
}

Received: September 9, 2015 Accepted: October 13, 2015 Online Published: October 19, 2015

doi:10.11114/jets.v4i1.1075

URL: http://dx.doi.org/10.11114/jets.v4i1.1075

\begin{abstract}
This study aims to determine how the history teaching career is perceived by prospective history teachers who attended the pedagogical formation program in Adiyaman University in 2014-2015 academic year. The study was conducted through content analysis of 5 sets of essays dealing with various aspects of history teaching. The essays topics were chosen being inspired from the History Teacher's Special Field Competencies identified by Ministry of Education published in 2011. The participants of the study were 11 female and 13 male prospective history teachers who did not have teaching experience except for the teaching practice in pedagogical formation program. Each participant submitted 5 essays, each with a different topic. The topics were accepted as the main themes. Analysis did not reveal a consistency between their objectives in teaching history, their teaching and testing methods. In the light of the results, some suggestions were made on history teaching as second career, history teaching practices at universities and testing methods at secondary and high schools.
\end{abstract}

Keywords: history teaching, teacher training, history curriculum

\section{Introduction}

Political regimes influence and regulate society, and, thus, determine the content and form in which this content is presented. Creation of social identities, statues and belonging process is instrumentalized through education. History teaching takes on an important role (Abens, 2015) during that process. Then Political expectations from formal educational institutions are best traced in the curricula of liberal arts, amongst which history has the crucial role (Vickers, 2005).

Political systems exploit history and history teaching to warranty their existence through either developing patriotism and nationalism or dictating obedience to the state with its assistance (Kello \& Wagner, 2014; Korostelina, 2013; Phillips, Goalen, McCully, \& Wood, 1999) or use it for the purpose of propanganda of the existing regime through legitimization and glorification of its order (Abens, 2015 Aslan, 2012; Köken, 2002; Nurdoğan, 2014). Using history teaching as the social cement has gone far beyond national application since the creation of European Union and is being exploited to homogenize a continent within a common history (Yllmaz, 2007). Providing that it is taught under no influence of biases or political impositions, history will serve in raising universal citizens (Güven, 2002; Zembylas \& Kambani, 2012). History, as do the other liberal arts, creates an available climate and atmosphere to impose ideological or philosophical preferences (Ata, 2012).

History, once being the knowledge and science of nobles, politicians and rulers (Safran, 2002), has presently changed into daily knowledge of an average citizen and being taught as a compulsory subject -even starting from the first grade of primary education (Reitano \& Green, 2013) in certain countries.

In Turkey, history teaching was entrusted with unprecedented objectives as one means of citizenship education in the Second Constitutional Period. Creation of "sufficient homogeneity among its citizens to survive as one society (Durkheim, 1922, p. 109)" reflected on curricula either directly or tacitly. In an attempt to meet the flagrant necessity to survive as one society, history teaching was questioned both in terms of content and methodology. However, the changes in content and language did not correspond to the methodology (Ünişen, 2013, p. 144). The perpetual changes in history curricula (Akagündüz, 2014; Kahveci, 2007, p. 88; Köken, 2002, pp. 332-337) did not go beyond preparing new textbooks. As teachers did not participate in these changing processes, their teaching methods remained traditional with the content of textbooks supplied by the state (Safran, 2002). 


\subsection{History Teacher Training in Turkey}

Problems experienced in teacher training in crash of Ottoman Empire were inherited by the just-established Turkish Republic. Having sufficient history content knowledge to pass the examination was adequate to be appointed as teacher from 1870 to 1911. The first history teachers with formal education in Daru'l-fünûn (Ottoman University), faculty of letters were appointed in 1911. In 1926, Gazi Muallim Mektebi (a school normal superior) was established to train history teachers for secondary schools, and in 1940, Ankara University, Faculty of Language, History and Geography started training history teachers for high schools (Safran, 2002). An examination of teacher training systems from late Ottoman period up-to-present reveals that it lacks a tradition. Branch teacher training and staffing procedures are asserted not to share any philosophical, sociological and pedagogical basis, and hence not institutionalized (Bilir, 2011; Kavcar, 2002). Especially the measures taken to meet the urgent and large scale teacher shortages are harshly criticized due to their low quality outcomes (Deringöl, 2007; Özoğlu, 2010).

\subsection{Rationale of the Present Study}

Teachers' characteristics and collegial factors are crucial in determining the curriculum implementation (Fullan, 2007, p. 89). History teachers with a powerful pedagogical content knowledge are observed to prefer many alternative teaching methods to traditional narration to create the cognitive and emotional behaviors (Veccia, 2004; Wiersma, 2008) whereas the inexperienced or the ones with inefficient pedagogical content knowledge track the textbooks and perceive the lowest level in cognitive domain as the ultimate objectives of the history (Virta, 2002).

Most of the teacher candidates -if not all- of liberal arts emphasize the effect of their high school teachers on their career planning as high school teachers (Kaya, Aslan, \& Günal, 2013) and naturally have the tendency to teach in the way they were taught. That is, their practical learning experiences will guide their teaching methods. As a result, history teaching has changed into relaying a pile of rote knowledge inherited unmethodically, congealed in textbooks and teachers' narrations (Ata \& Keçe, 2014) rather than being one of the means to develop critical thinking, problem solving, researching, interpreting, reasoning, etc. higher level cognitive skills (Aslan \& Akçali, 2007; Beyer, 2008; Blanco \& Rosa, 1997).

The studies in history teaching literature are made up of the participants in the field as teachers and students of history teaching departments. The problems examined are of the teachers and candidates with regular history teaching education, who take pedagogical content knowledge courses with content knowledge and other subsidiary courses concurrently. Literature lacks studies sampling the candidates taking pedagogical formation courses as an autonomous module in history teaching following the bachelor degree. Present study explored to what extend the prospective history teachers who attend the pedagogical formation program develop a history teacher identity in aspect of perceiving the career and meeting the basic requirements of career regarding teaching-learning processes. The results can be useful in paving the paths for improving the curriculum development for pedagogical formation and in-service training programs for employed teachers as a post-graduation assistance.

\section{Method}

The present study was conducted as document analysis. Data for the study was gathered over a period of five weeks. Each week, following a discussion of 10 to 15 minutes, participants were asked to answer an essay type question on the same topic addressing history teaching instructors at university. The 120 essays written by 24 prospective secondary and high school history teachers were subjected to content analysis. Although the data was gathered from the same individuals selectively sampled and tracked over the research period, as is done in cohort and panel studies, and as no measurement was carried to track the changes over the time, the research loses some characteristics of a longitudinal one (Cohen, Manion, \& Morrison, 2012, pp. 2011-2012).

The participants were told the data would be used in a research on efficiency of the program they attended; they could leave or miss any session; the questions did not have a definite correct answer and their answers would not affect their performance in anyway. In an attempt to assure the validity, the research was conducted with enough participants to elicit various opinions, the questions were posed clearly, the data were gathered in written form from the participants (Cohen et al., 2012, p. 150; Yin, 2012, p. 79). In order to encourage the participants to focus on the content, each time they were assigned to write, they were also reminded not to bother with mechanics of essay writing and, nor would they receive any critical feedbacks dealing with visual validity of their works. They were also reminded that the questions did not have a true and correct answer so as not to satisfy the researcher's expectations.

\subsection{Participants}

The participants were selected on the base of volunteer out of 50 prospective secondary and high school history teachers who attended "pedagogical formation" program implemented at Adiyaman University in 2014-2015 academic year. "Graduation from history department of faculties of arts and sciences" and "having no experience of teaching practice 
either in state or private schools" were the criteria for sampling. 16 of the prospective teachers had teaching experiences over at least one academic year at either state or private schools for tuition or training centers established for university admission examinations and transition from primary school to secondary school examinations. In accordance with criterion sampling, they were excluded. Another group of 10 prospective teachers did not attend some of the sessions, mostly due to absenteeism. The research was conducted with 24 participants, 13 male and 11 female, ranging 22-25 years in age and averaging 23,17 .

The study was conducted in the latter term of the program. The participants took Introduction to Education, Teaching Methods, assessment and evaluation in education, classroom management and educational psychology courses in the prior term. In the latter term, they attended special teaching methods, instructional technologies and designing teaching materials, teaching practice and two selective courses selected among 16 courses. Data were gathered starting from the $10^{\text {th }}$ week of the latter term, when each candidate had over 50 hours of teaching experience in state schools and took at least $70 \%$ of special teaching methods and instructional technologies and designing teaching materials courses.

\subsection{Instrumentation and Data Collection}

Starting from the $10^{\text {th }}$ week of the latter term in academic year of 2014-2015, the participants were assigned to write essays on following topics respectively;

1. What educational attainments are the core objectives of history teaching in states schools?

2. What characteristic features distinguish a historian from a history teacher?

3. How do you plan to cope with contradictory issues regarding official-real historical discourses?

4. Discuss the probability of alternative history teaching methods to narration.

5. Taking the objectives of history teaching into consideration, discuss the most efficacious testing method for history teaching.

The essays topics were ordered in assignment that each would deal with one of the stages in curriculum development; starting with objectives, and ending the cycle in evaluation process.

Essays on each topic were submitted one week after the assignment and in the end of the term each participant had completed a set of 5 essays. As they had their names on, a file for each participant was kept and their papers were filed duly during the data gathering process.

\subsection{Procedure}

Out of 50 files, 16 due to prior experiences of teaching experiences of the participants, and 10 due to missing at least one of the topics, were excluded. 24 files with a set of 5 essays were selected for the analysis.

The essays were grouped under the 5 titles. The papers were scanned using and automatic document feeder (ADF) and saved as portable document format (PDF). Each set of topics was first read over to see the scope and nature of the data, which also led to create a coding system.

\subsection{Data Analysis}

The data, scanned and saved as one single file in portable document format, was imported to Atlas-Ti (v7.5), one of the qualitative data analysis and research softwares. Each set of the essays were read and coded concurrently. The themes were created from the codes according to the context which they were used in, and the results were given statically and quasistatiscally in tables. In quotations, PHTXX acronym, standing for (P)rospective (H)istory (T)eacher, was used to ensure anonymity.

\section{Results}

The study was conducted on 24 participants with bachelor's degrees in history from faculties of arts and sciences. The participants did not have any previous teaching experience in history except for the one as part of the pedagogical formation program they attended. The pedagogical knowledge they implemented in their essays is presumed to be achieved through the program.

Demographics of the participants were briefed in Table 1.

Table 1. Gender*Age Cross-tabular Demographics of Participants

\begin{tabular}{ccccccccc}
\hline \multirow{5}{*}{ Gender } & & \multicolumn{9}{c}{ Age } & & & \\
\cline { 2 - 7 } & & 22 & 23 & 24 & 25 & Mean & Total & $(\%)$ \\
\cline { 2 - 8 } & Female & 5 & 3 & 2 & 1 & 22,91 & 11 & 45,83 \\
& Male & 1 & 7 & 4 & 1 & 23,38 & 13 & 54,17 \\
& Total & 6 & 10 & 6 & 2 & 23,17 & 24 & \\
& Percentage & 25,00 & 41,67 & 25,00 & 8,33 & & & 100,00 \\
\hline
\end{tabular}

Table 1 shows that, of the 24 participants, 11 are female ranging 22-25 in age with the mean of 22,91 and mod of 22 ; 
and 13 male ranging 22-25 with the mean of 23,38 and mod of 23. Age average of the participants is 23,17 .

\subsection{Educational Attainments of History Teaching}

In analyzes of the essays written under the heading of "objectives of history teaching", prospective history teachers were found to presume 35 objectives for history teaching. The codes in their presumptions were sorted out in four themes -as socio-national objectives, its contribution into individual development, cultural development and its contribution into universal objectives of history teaching (Table 2).

Table 2. Educational Attainments of History Teaching

\begin{tabular}{|c|c|c|c|}
\hline Themes & Codes & $\mathrm{F}$ & $(\%)$ \\
\hline \multirow{7}{*}{$\begin{array}{c}\text { Socio-National } \\
\text { Objectives }\end{array}$} & Creating national identity & 24 & 100,00 \\
\hline & Fostering patriotism & 9 & 37,50 \\
\hline & Legitimizing the ruling political regime & 5 & 20,83 \\
\hline & Contributing domestic peace & 3 & 12,5 \\
\hline & Creating historical identity & 2 & 8,33 \\
\hline & Assimilating the differences & 1 & 4,17 \\
\hline & Teaching civil rights and responsibilities & 1 & 4,17 \\
\hline \multirow{14}{*}{$\begin{array}{c}\text { Individual } \\
\text { Development }\end{array}$} & Teaching thinking/critical thinking & 14 & 58,33 \\
\hline & Developing a clear vision of future & 11 & 45,83 \\
\hline & Avoiding to make a mistake twice/planning future & 8 & 33,33 \\
\hline & Understanding the present & 5 & 20,83 \\
\hline & Teaching scientific thinking skills & 4 & 16,67 \\
\hline & Contributing linguistic development & 3 & 12,5 \\
\hline & Teaching moral values & 2 & 8,33 \\
\hline & Bringing up highbrow individuals & 2 & 8,33 \\
\hline & Provoking research incentives & 2 & 8,33 \\
\hline & Helping make sound decisions & 1 & 4,17 \\
\hline & Developing imaginative power & 1 & 4,17 \\
\hline & Contributing writing skills & 1 & 4,17 \\
\hline & Contributing students success in examination held country-wide & 1 & 4,17 \\
\hline & Preparing students for their social adult roles & 1 & 4,17 \\
\hline \multirow{11}{*}{$\begin{array}{c}\text { Cultural } \\
\text { Development }\end{array}$} & Transmitting national culture & 13 & 54,17 \\
\hline & Developing cultural responsibility/identity & 9 & 37,5 \\
\hline & Keeping and/or transferring immaterial inheritance & 7 & 29,17 \\
\hline & Embracing and preserving the artifacts & 5 & 20,83 \\
\hline & Developing social responsibility & 5 & 20,83 \\
\hline & Making good citizens & 4 & 16,67 \\
\hline & Teaching social values & 3 & 12,5 \\
\hline & Keeping the interest in past alive & 2 & 8,33 \\
\hline & Teaching naturality of socio-cultural changes and current differences & 2 & 8,33 \\
\hline & Respecting the past & 2 & 8,33 \\
\hline & Teaching the role models in national past & 2 & 8,33 \\
\hline \multirow{3}{*}{$\begin{array}{l}\text { Universal } \\
\text { Objectives }\end{array}$} & Teaching universal values & 5 & 20,83 \\
\hline & Understanding other nations/societies & 4 & 16,67 \\
\hline & Teaching the role of national past comparing with of other nations' & 2 & 8,33 \\
\hline
\end{tabular}

The participant thought that history teaching had socio-national, individual, cultural and universal objectives. As stood out in the table (2), socio-national objectives outweighed all other objectives in frequencies, and objectives dealing with contribution to individual development did in quantity.

As socio-national objectives, the participants thought that history teaching help to create national identity (100\%); foster patriotism $(37,50 \%)$, legitimizing the ruling political system $(20,83 \%)$, contribute to domestic peace $(12,5 \%)$, create historical identity $(8,33 \%)$, assimilate the differences $(4,17 \%)$, teach civil rights and responsibilities $(4,17 \%)$.

History teaching was thought to affect individual development in terms of learning thinking/critical thinking (58,33\%), developing a clear vision of future $(45,83 \%)$, planning future $(33,33 \%)$, understanding the present $(20,83 \%)$, teaching scientific thinking skills $(16,67 \%)$, contributing linguistic development $(12,5 \%)$, teaching moral values $(8,33 \%)$, bringing up highbrow individuals $(8,33 \%)$, provoking research incentives $(8,33 \%)$, and helping make sound decisions, developing imaginative power, contributing writing skills, contributing students success in examination held country-wide and preparing students for their social adult roles at 4,17\% each.

History teaching was also regarded to play a role in transmission of social and cultural accumulation. The participant thought that history aimed to transmit national culture $(54,17 \%)$, develop cultural responsibility or identity $(37,5 \%)$, keep and/or transfer immaterial inheritance $(29,17 \%)$, teach why and how to embrace and preserve the artifacts $(20,83 \%)$, develop social responsibility $(20,83 \%)$, make good citizens $(16,67 \%)$, teach social values $(12,5 \%)$, keep the 
interest in past alive $(8,33 \%)$, teach naturality of socio-cultural changes and current differences $(8,33 \%)$, respect the past $(8,33 \%)$ and teaching the role models in national past $(8,33 \%)$.

The participant stated that history had also objectives such as teaching universal values $(20,83 \%)$, help the learners understand other nations and societies $(16,67 \%)$ and created opportunity to teach national past comparing with of other nations'.

The participants believed that history teaching was a means of keeping unity and solidarity, an element of social and cultural inheritance and stability besides its contribution to individual development and citizenship education. The educational objectives listed above, if not in those words but in a homoionym way, are mentioned in attainments of history curriculum except for "assimilation". Furthermore, all of the programs of liberal arts, including history, encourage pluralism and multi-cultural approaches to the content. As seen in the table, "assimilating differences" was contradicted by $8,33 \%$ of the participants the code of "teaching naturality of socio-cultural changes and current differences".

\subsection{Distinguishing Characteristics of a Historian and a History Teacher}

The second essay explored how the participants perceived either profession, and what attitudes they had towards them. The codes found out in their expository essays mirroring their views regarding a historian and a history teacher were tabulated below.

Table 3. Participants' Views about the Characteristics Distinguishing a Historian from a History Teacher

\begin{tabular}{|c|c|c|c|c|}
\hline & Themes & Codes & $\mathrm{F}$ & $(\%)$ \\
\hline \multirow{20}{*}{$\begin{array}{l}\text { History } \\
\text { Teacher }\end{array}$} & \multirow{8}{*}{$\begin{array}{c}\text { Professional } \\
\text { Necessity }\end{array}$} & Having pedagogical content knowledge besides being a historian & 7 & 29,17 \\
\hline & & Objective* & 3 & 12,50 \\
\hline & & Being more social & 2 & 8,33 \\
\hline & & Subjective* & 2 & 8,33 \\
\hline & & Relating past and future & 1 & 4,17 \\
\hline & & Rhetorician & 1 & 4,17 \\
\hline & & Creating collective consciousness & 1 & 4,17 \\
\hline & & Being a model in social roles & 1 & 4,17 \\
\hline & \multirow{5}{*}{$\begin{array}{l}\text { Curriculum } \\
\text { Fidelity }\end{array}$} & Restricted with the curriculum/the textbooks & 19 & 79,17 \\
\hline & & Relaying rote information & 17 & 70,83 \\
\hline & & Serving political objectives of the state/ministry of education & 4 & 16,67 \\
\hline & & Preparing students for examinations & 2 & 8,33 \\
\hline & & Regarding the content unquestionable & 1 & 4,17 \\
\hline & \multirow{4}{*}{$\begin{array}{l}\text { Academic } \\
\text { Quality }\end{array}$} & Having horizontal but skin-deep knowledge & 3 & 12,50 \\
\hline & & Having content knowledge & 2 & 8,33 \\
\hline & & Researcher/Scientist & 2 & 8,33 \\
\hline & & Having more (extra) features than a historian & 2 & 8,33 \\
\hline & \multirow{3}{*}{$\begin{array}{l}\text { Cultural } \\
\text { Relayer }\end{array}$} & Creating and developing cultural values & 3 & 12,50 \\
\hline & & Relaying national identity & 3 & 12,50 \\
\hline & & Shaping future & 2 & 8,33 \\
\hline \multirow{15}{*}{ Historian } & \multirow[t]{2}{*}{ Profession } & An average profession/source of income & 3 & 12,50 \\
\hline & & Scientific & 2 & 8,33 \\
\hline & Professional & Less skillful in teaching & 1 & 4,17 \\
\hline & \multirow[t]{2}{*}{ Necessity } & Having new perspectives/viewpoints & 1 & 4,17 \\
\hline & & Interpretive & 1 & 4,17 \\
\hline & \multirow{8}{*}{$\begin{array}{c}\text { Disciplinary } \\
\text { Necessity }\end{array}$} & Objective & 13 & 54,17 \\
\hline & & Researcher & 12 & 50,00 \\
\hline & & Producing knowledge & 7 & 29,17 \\
\hline & & Freethinking/Critical & 6 & 25,00 \\
\hline & & Contributing science & 5 & 20,83 \\
\hline & & More informed & 5 & 20,83 \\
\hline & & Specialized in one field & 2 & 8,33 \\
\hline & & Making use of various sources & 1 & 4,17 \\
\hline & Cultural & Faithful to his past & 1 & 4,17 \\
\hline & Relayer & Relating past and future & 1 & 4,17 \\
\hline
\end{tabular}

As seen in the table (3) a history teacher was depicted according to the requirements of their profession while a historian was described according to the requirements of their discipline.

The codes reflecting their views of a history teacher were thematized under titles as professional necessities, curriculum implementation, academic qualities and cultural relayer. The participants thought that a history teaching as a career required having pedagogical content knowledge besides being a historian $(29,17 \%)$, being objective $(12,50 \%)$, more social $(8,33 \%)$, relating past and future $(4,17 \%)$, being a rhetorician $(4,17 \%)$, creating collective consciousness $(4,17 \%)$, 
being a model in social roles $(4,17 \%)$. Two participants thought that they might be subjective in some matters, which contradict with their objectivity with a higher percentage and the codes listed in curriculum fidelity.

The codes dealing with curriculum implementation created a common ground with the highest frequencies. They thought a history teacher was restricted with and led by the curriculum. They described a history teacher as being restricted with the curriculum and textbooks $(79,17 \%)$, relaying rote information $(70,83 \%)$, serving political objectives of the state or ministry of education $(16,67 \%)$, preparing students for examinations $(8,33 \%)$ and regarding the content unquestionable $(4,17 \%)$.

Academic qualities of a history teacher were thought as having extensive but skin-deep knowledge (12,50\%), having content knowledge $(8,33 \%)$, researcher and scientist $(8,33 \%)$ and having more (extra) features than a historian $(8,33 \%)$.

Relaying cultural accumulation was thought to be performed by a history teacher better. They thought history teaching entailed creating and developing cultural values $(12,50 \%)$, relaying national identity $(12,50 \%)$ and shaping future society $(8,33 \%)$.

Disciplinary requirements outweighed professional requirements when the participant described a historian. They described a historian as being (more) objective $(54,17 \%)$, a researcher $(50,00 \%)$, producing knowledge $(29,17 \%)$, thinking freely and critically $(25,00 \%)$, contributing the science $(20,83 \%)$, (more) informed (than a history teacher) $(20,83 \%)$, specialized in one field $(8,33 \%)$, making use of various sources $(4,17 \%)$. As a result of doing science, he was also claimed to be treating scientifically $(8,33 \%)$, being less skillful in teaching $(4,17 \%)$, having new perspectives and viewpoints $(4,17 \%)$, being interpretive $(4,17 \%)$.

Although the participants were told to think of distinguishing characteristics of either career, still certain common attribution emerged.

Table 4. Participants' Views about the Common Characteristics a Historian and a History Teacher

\begin{tabular}{lcccc}
\hline \multirow{2}{*}{ Common Characteristics } & \multicolumn{2}{c}{ Historian } & \multicolumn{2}{c}{ History Teacher } \\
\cline { 2 - 5 } & $\mathrm{F}$ & $(\%)$ & $\mathrm{F}$ & $(\%)$ \\
\hline Researcher & 12 & 50 & 2 & 8,33 \\
Same & 2 & 8,33 & 7 & 29,17 \\
Supporting official ideology & 1 & 4,17 & 4 & 16,67 \\
Relating past to future & 1 & 4,17 & 1 & 4,17 \\
\hline
\end{tabular}

As shown in Table 4, both a historian and a history teacher were regarded as researchers, supporting the official ideology, relaying or transmitting the cultural accumulation and pursuing the same career with different frequencies.

"Being limited within textbooks and curriculum" and "relaying information" hit the top among the unapproved features which were thought of history teachers. These are not elements of the program, on the contrary, teachers are encouraged to make use of various resources to enrich their presentations, and also make use of flexibility of the curriculum. The participants found the historian to be far more objective than history teachers; however, the curriculum dictates teachers to be objective and help their students develop objective perspectives. The subjectivity, which was attributed to a history teacher, may have resulted from the title of the essay, which dictates to find out the differences.

In general, participants perceive history teachers less qualified or even inferior when compared with historians in collegial aspect; historians are described with more respectful attributes. That result can be interpreted as they respect the historian and feel themselves as a historian more. Although both are regarded as acting in the same scene, the leading and admired role is played by the historian as said by PHT06(M);

"The best analogy, I think, will be the cases of a cook and a waiter; the prior creates a dish making use of so many ingredients while the latter serves it to the table in his way."

PHT12(F): "The last discovered data always tends to be the correct. This mission is of a historian. He has to research and share his results with the ones concerned. That is, a historian produces the knowledge and a history teacher teaches and disseminates it."

\subsection{Reactions against Problems in Teaching Process}

Participants were asked to write down their reaction against any contradictory issue in teaching process, preferably arisen on real history-official history contradiction. Their reactions shed light on the side they stood (Table 5). 
Table 5. Reaction to Arising Contradictory Issues in Classes

\begin{tabular}{clcc}
\hline Themes & \multicolumn{1}{c}{ Codes } & F & $(\%)$ \\
\hline Attitude towards & Rather not have discussions about contradictory issues & 19 & 79,17 \\
Emergence of & Welcome discussions & 2 & 8,33 \\
Discussion & Not stated & 3 & 12,5 \\
& Being loyal to the textbooks & 8 & 33,33 \\
\multirow{2}{*}{ History Teacher } & Assuring them of the correctness of the textbooks & 2 & 8,33 \\
Reaction & Being objective if a discussion arises & 2 & 8,33 \\
& Reminding them of the examinations & 1 & 4,17 \\
& Using contradictions as research assignments & 1 & 4,17 \\
\multirow{2}{*}{ Historian Reaction } & Prefer being objective (always) & 9 & 37,5 \\
& Explaining the real situation & 7 & 29,17 \\
& Researching more & 7 & 29,17 \\
& Telling his own knowledge (objective) & 3 & 12,5 \\
\hline
\end{tabular}

As shown in table 5, majority of participants $(79,17 \%)$ wished not to have disputative matters during classes. Their reactions were thematized under two heading, reactions as a historian and reactions as a history teacher. The frequencies showed that their reaction as historians were much stronger. As history teachers their reaction focused on teaching the content. Using discussion as a method and its contribution to engagement scored rather low $(4,17 \%)$ among the reactions as history teacher. But contradictory matters were stated to interest them more and lead them to research $(29,17 \%)$.

Their reactions as history teachers were sequenced as being loyal to the textbooks $(33,33 \%)$, assuring their students of the correctness of the textbooks $(8,33 \%)$, being objective if a discussion arose $(8,33 \%)$, reminding them of the examinations $(4,17 \%)$, using contradictions as research assignments $(4,17 \%)$. Their reactions as historian were found to be more rational as preferring objectivity $(37,50 \%)$, explaining the real situation $(29,17 \%)$, researching the matter himself $(29,17 \%)$ and telling his own knowledge $(12,5 \%)$.

Except for "using contradictory matters as research assignments", all other activities are to be carried out by the prospective teachers. That is, their perception of a historian and a history teacher (Table 3) leads them to the way they will react in: they do not think of the opportunities to use them in helping students learn, but focus on the content in a completely teacher-centered manner, instead. The prominence of the content hints that the participants prefer a scientific identity and are not ready to amalgamate it with its pedagogy. Extremely unscientific manners such as "persuading students of correctness of content" and "content is not to discuss but to learn for the exams" are associated with each other, and they do not have either curricular or pedagogical basis.

On the other hand, their unwillingness to have discussions in the classes contradicts both with their history teacher and historian characteristics, who are critical themselves and ought to help development of critical thinking.

\subsection{Probability of Alternative History Teaching Methods to Traditional Methods}

Participants were asked to write a persuasive essay discussing the best alternative to traditional narrative presentation to achieve cognitive, emotional and psychosomatic engagement on the part of their prospective students. The methods/technics, which were proposed by the participants, were sequenced in two themes as the ones enriching the learning environment and the ones providing students engagement as shown below (Table 6). We must bear in mind that those methods/technics were not discussed as stand-alone but believed to support the narration.

The participants thought the traditional narration method was irreplaceable, and instead of seeking an alternative method, it could be used along with some others to provide students' engagement, and the content could be presented in an enriched learning environment.

The participants thought that traditional narrative history teaching methods had to be supported with using digital visuals $(25,00 \%)$, watching documentaries $(16,67 \%)$, using visuals (photos, pictures, cartoons, comics) $(8,33 \%)$ and attending conferences, analyzing historical documents, organizing exhibitions, presenting content in form of stories $(4,17 \%)$ each. Dramatization and role play $(29,17 \%)$, organizing trips to historical places $(29,17 \%)$, project based learning $(20,83 \%)$ scored the highest frequencies as measures taken to provide students engagement. Cooperative and collaborative studies $(8,33 \%)$, reading assignments $(8,33 \%)$ and question-answer method $(8,33 \%)$ were stated to encourage the students' engagement. The remainder measures, as brain storming using concept maps, discussion method, using games, making use of oral history and presentation by students, were preferred by $4,17 \%$ each.

The frequencies suggest that they have difficulty to move away from traditional and teacher centered pedagogy to achieve the attainments of history teaching besides the content. Out of the measures which they plan to take, only dramatization and role play regarded to spark their students' emotional engagement directly, while others address cognitive engagement, which do not inspire long term knowledge retention. 
Table 6. Participants Views on Probable Alternatives and Aids to Narration

\begin{tabular}{clcc}
\hline \multicolumn{1}{c}{ Themes } & Codes & $\mathrm{F}$ & $(\%)$ \\
\cline { 2 - 4 } & Using digital visuals & 6 & 25,00 \\
& Watching documentaries & 4 & 16,67 \\
Enrichment of & Using visuals & 2 & 8,33 \\
Environment & Attending conferences & 1 & 4,17 \\
& Analyzing Historical documents & 1 & 4,17 \\
& Organizing exhibitions & 1 & 4,17 \\
& Presenting content in form of stories & 1 & 4,17 \\
\hline & Drama/role play & 7 & 29,17 \\
& Organizing trips & 7 & 29,17 \\
& Named many student centered technics (depends) & 6 & 25,00 \\
& Research assignments/projects & 5 & 20,83 \\
& Constructivist methods & 3 & 12,5 \\
& Assigning students to read books & 2 & 8,33 \\
& Cooperation/collaboration & 2 & 8,33 \\
Fostering Student & 2 & 8,33 \\
Engagement & Question-answer & 1 & 4,17 \\
& Brain storming & 1 & 4,17 \\
& Using concept maps & 1 & 4,17 \\
& Discussion method & 1 & 4,17 \\
& Games & 1 & 4,17 \\
& Oral history & 1 & 4,17 \\
\hline
\end{tabular}

\subsection{Assessment and Evaluation}

From the essay intending to elicit participants' views on the most efficacious testing method for history teaching, item types used in testing and the reasons for choosing those types were gathered in two themes each (Table 7).

Table 7. Participants' Views on Testing History Performance

\begin{tabular}{|c|c|c|c|c|}
\hline & Themes & Codes & $\mathrm{F}$ & $(\%)$ \\
\hline \multirow{10}{*}{ Testing } & \multirow{4}{*}{ Rote learning } & Multiple Choice & 10 & 41,67 \\
\hline & & Filling in blanks & 2 & 8,33 \\
\hline & & Short answer & 2 & 8,33 \\
\hline & & True-false & 1 & 4,17 \\
\hline & \multirow{4}{*}{$\begin{array}{l}\text { Historical } \\
\text { learning }\end{array}$} & Essay type questions & 8 & 33,33 \\
\hline & & No exam of any type & 2 & 8,33 \\
\hline & & Research assignment & 2 & 8,33 \\
\hline & & Oral examination & 1 & 4,17 \\
\hline & \multirow{2}{*}{ Other } & Depends & 5 & 20,83 \\
\hline & & Testing after each subject & 3 & 12,50 \\
\hline \multirow{6}{*}{$\begin{array}{c}\text { Reason for } \\
\text { Choosing } \\
\text { Testing Type }\end{array}$} & \multirow{3}{*}{$\begin{array}{l}\text { Achieving } \\
\text { history skills }\end{array}$} & Developing thinking skills & 5 & 20,83 \\
\hline & & Year-long engagement and interest & 2 & 8,33 \\
\hline & & Exams degrade the objectives & 1 & 4,17 \\
\hline & \multirow{3}{*}{$\begin{array}{l}\text { Teaching } \\
\text { content }\end{array}$} & Realizing content validity & 7 & 29,17 \\
\hline & & Objectivity in assessment & 1 & 4,17 \\
\hline & & Preparing Ss for nationwide held examinations & 1 & 4,17 \\
\hline
\end{tabular}

The participants favored multiple choice items (41,67\%) in testing their students' history performances. Multiple choice items, filling in blanks $(8,33 \%)$, short answer $(8,33 \%)$ and true-false items $(4,17 \%)$ suggest rote learning. Participants' decisions on that testing type are dictated by realizing the content validity $(29,17 \%)$, objectivity in assessment $(4,17 \%)$ and preparing their students for the nation-wide held transition examinations. The participants who favored open-ended essay type questions $(33,33 \%)$ and oral examination $(4,17 \%)$ thought that their students could not express richness of thought in confines of prevailing multiple choice, short answer and true-false question, nor did they support developing thinking skills $(20,83 \%)$. Some participants discussed indecency of examinations in history $(8,33 \%)$, either claiming examinations degraded the objectives of history teaching $(4,17 \%)$ or proposing an assessment based on observation of year-long students' engagement and interest $(8,33 \%)$.

The anxiety about objectivity, reliability, validity and their performances in preparing their students for examinations are observed to subdue the objectives of history teaching. In a comparison with the objectives of history teaching (Table 2), only two codes, namely developing thinking skills and preparing students for nationwide held examinations, were found to overlap.

\section{Discussion}

The prospective history teachers, whose views were listed in the study, were graduated from history departments of 
faculties of arts and letters, which implement a program that strictly emphasize using methods reserved exclusively for the discipline, using primary and secondary resources, being objective and working without making any concession on being scientific. Their major is intended to train and educate historians. And the pedagogical formation program they attended was designed to upskill individuals with a major as teachers for secondary and high schools. As named by Reitano \& Green (2013), they are "subject-knowers" changing into "subject-teachers". The program includes seven common and three special courses for each discipline, totaling 20 credit hours. They had 155 credits for their major in history, which means the formal education they received to be history teachers equals less than $13 \%$ of their educations to be historians. History teachers' efficiency domains are classified as 'content knowledge, pedagogical content knowledge and knowledge of attitudes and values'(Safran, Ata, Türkan, Gümüşlü, \& Cansever, 2011). That is, one third of their knowledge is formed through 155 credits and remaining two thirds is expected to emerge or shape through 20 credits. On the other hand, regular history teachers' training and education program, which requires taking 168 credits for graduation, allocates $20,83 \%$ of total courses to pedagogical content knowledge and remaining $79,17 \%$ to content knowledge and other supplementary courses. In regular history teaching departments of faculties of education pedagogical content knowledge courses and other courses are taught concurrently in a more systematical way; pedagogical content knowledge courses are distributed to eight terms starting from the general ones to the most specialized, namely 'Introduction to Educational Sciences' to 'Teaching Practice'.

Present study explored how they felt themselves and would react in various scenes of implementing history curricula. The results of the research are concluded and discussed below systematically:

\subsection{Educational Attainments of History Teaching}

Participants shared the view that history teaching had social and individual attainments as detailed in Blanco \& Rosa's (1997) study. The socio-national objectives prescribed for history teaching by participants can be rephrased as values education as they all aim to gather the individuals on common and respected basis. These objectives are dictated by all education policies and embedded especially in liberal arts' curricula explicitly or latently (Abens, 2015; Aslan \& Akçall, 2007; Clark, 2006, pp. 25-47; Gutiérrez, Ricardo, \& Segura, 2015; Haynes, 2009; Jones, 2002; Kello \& Wagner, 2014; Korostelina, 2013; Swartz, 1997; K. Yılmaz, 2008).

Findings also support some other studies conducted with high school students showing that the participants were of the opinion that history teaching aimed at teaching the past to individuals, learning from past experiences (Magendzo \& Toledo, 2009), interpreting the future, creating consciousness, contributing cultural development, fostering patriotic feelings and historical identity (Demircioğlu, 2006; Güven, 2002).

History teaching is accepted to be effective in contributing to individual development both in quality and variety. Developing thinking skills were the most prominent of all, however, the participants did not mention the standards of historical thinking, which are universally acknowledged and stated in the curricula (MNE, 2011, pp. 8-12).

Educational attainments of history also include answers to what history is. When the results are to interpret for this question, the participants identify history as a body of knowledge needed mastering, which contradicts with studies conducted in student-centered learning climates (Nye et al., 2011).

\subsection{A Historian and a History Teacher}

The participants' views about who a historian is may be regarded as what they were taught rather than what they thought, and about who a history teacher is vice versa. One of the prevailing features in describing a historian and a history teacher was observed through the adjectives they attributed to each profession: benefiting from the available resources was described as "being objective" for a historian whereas the freedom of choosing available resources might be "being limited" for a history teacher; benefiting from various resources and presenting results within a report was applauded as "a researcher" but a history class presentation prepared in the same manner was seen as "relaying rote knowledge". Their perception of a history teacher contradicts with the curricula. As example, making use of various sources out textbook is mentioned 15 times in $10^{\text {th }}$ grade history curriculum (MNE, 2011). In general, many common characteristics in either profession were described through appreciated adjectives for historians but in a decrial manner for history teachers. Their emphasize on content knowledge implies that being a subject specialist is believed to entail its teaching as well, as observed by Kaya et al (2013).

The results dealing with the description of a history teacher are parallel with other studies; in which they were described as relaying knowledge, storing knowledge, leading the way to future, watching the curriculum, shaping the society, and researchers (Aktekin, 2013). Dinç (2006), in his study, which compared previous and current history curriculum, found teachers to adhere the curriculum more than teacher candidates and academicians, which conformed the participants' views about the teachers' tendencies to curriculum fidelity regarding the content. 


\subsection{Disputative Matters in History Classes}

The results dealing with challenges triggered by the content actually disclosed the participants' adequacies in class management and particularly in teaching methods. The high frequency of unwillingness to have discussions may be interpreted as either rejection of both roles and identities or a vague identity or role confusion. Because discussion is a notable method to clear issues of their disputative points in social sciences (Klein, 2010) as well as being an effective teaching method enabling cognitive engagement on the part of students, developing thinking skills and democratic participation. Their attitudes towards the discussions led us to concluding that they would conduct their classes in a teacher-centered manner.

The strategies to be deployed by the prospective teachers to cope with controversial issues in history teaching had similarities with the ones in many studies, and trying to avoid discussion while teaching seemed to be the first choice, which was encountered in few other studies due to various reasons (Clark, 2009; Gutiérrez et al., 2015; James, 2008; Zembylas \& Kambani, 2012).

\subsection{Teaching Methods}

As observed in Table 3, less than a third of participants $(29,17 \%)$ believed that having pedagogical knowledge besides the content knowledge would promote a historian into a history teacher while the remaining considers having the content knowledge or being a historian naturally entailed the art of teaching it. They did not believe that any method can ever replace traditional narration, but instead, presumed that they could be used as subsidiary and supporting narration or enrich the learning environment without remarkable consensus. This was not to interpret as resistance to change or anxiety about devaluing the factual knowledge in case of any child-centered teaching (Osborne, 2003) but rather as believing that the best method to teach was the only method they were taught in (Virta, 2002). Their teacher-centered approaches might also have resulted from class sizes or examination-based expectations dictated by schools and society (Gerwin \& Visone, 2006), or as discussed by Martell (2013) limited understanding of content might be leading them narrating history instead of doing it.

Still another point to make is that the methods they favored were more likely to serve socio-national attainments of history teaching, neglecting or overlooking its contribution to individual development of students.

Variety of supportive methods with low frequencies to teach indicated that they were hesitant about practicality of their suggestions, and their students would not do history as stated by Nichol \& Dean (2005, pp. 9-10). That means most of the participants highly tend to use traditional history teaching methods as do many history educators (Wiersma, 2008) but also intend to use technics fostering constructivist learning (Martell, 2014) as well.

\subsection{Assessment and Evaluation}

In assessment and evaluation process participants preferred the prevailing testing system in Turkey. The multiple choice-dominancy in testing is a consequence of schools' anxiety about nation-wide-held examination rather than any other rationale. The schools, as well as parents, prioritize the students' performance in nation-wide-held examinations, which are in multiple choice forms. Although the participants suggested testing following each class (or unit), periodic and summative as seen in some studies (Philpott, 2011), this was not to help students learn history skills but rather give them the chance of answering as many questions of different sources as possible.

No coherence was observed between the objectives they tailored for themselves as history teachers, their teaching methods to achieve their objectives and the way they would assess how successful their students were. The anxiety about objectivity, reliability, validity and their performances in preparing their students for examinations were observed to subdue the objectives of history teaching. In a comparison with objectives of history teaching (Table 2), only two codes were identified to overlap. The participants were aware of the necessity of discipline-based assessment and knew what it should be like as observed in Brown's (2013) study but they were not enthusiastic about using them for various reasons. On the other hand, they did not have any explanation on how higher cognitive domain skills could be attained through multiple-choice examinations or any other reminder-oriented question.

To sum up, they were aware of the majority of attainments of history teaching but had the tendency act as historian rather than history teachers in history teaching process.

\section{Implications}

The literature implies that history teaching is either a scientific art or an artistic science, developing after much demanding efforts. If it is to be a choice for second career, it requires a better-designed curriculum focusing on special teaching methods.

As the results show, history teaching is not constructed by each teacher candidate individually but inherited from practices of their teachers. The content seems to be relayed alongside its teaching method, which is narration oriented 
and teacher-centered. Then prospective history teachers need to witness student-centered methods being deployed by subject specialists in their pre-service periods.

Nation-wide held examinations avoid teachers conducting efficacious examinations in their subjects. Certain subjects, especially contributing thinking skills, social and individual development should either be excluded from those examinations or included with items which serve the attainments better.

\section{References}

Abens, A. (2015). Effects of authoritarianism on the teaching of national history: the case of Latvia. Paedagogica Historica, 51(1-2), 166-180. http://dx.doi.org/10.1080/00309230.2014.997749

Akagündüz, Ü. (2014). Dynastic and heroic history teaching in late Ottoman Period: Litte Ottoman history with maps and a summary of Ottoman history. Journal of Turkish History Teaching, 3(2), 112-143. http://dx.doi.org/ 10.17497/tuhed.62461

Aktekin, S. (2013). An analyse of believes regarding history teaching through metaphors. Theory and Practice in Education, 9(3), 211-228.

Aslan, E., \& Akçalı, A. A. (2007). History teaching as identity declaration. Dokuz Eylül University Journal of Buca Faculty of Education, (22), 125-132.

Ata, B. (2012). History teachers and their practices in students' memories (1882-1957). Journal of Turkish History Teaching, 1(1), 73-98.

Ata, B., \& Keçe, M. (2014). Factors affection students' history literacy level: A qualitative study based on teachers' views. Journal of Turkish History Teaching, 3(2), 1-23.

Barton, K. C., \& Levstik, L. S. (2004). Teaching history for the common good. New Jersey: Lawrence Erlbaum Associates.

Beyer, B. K. (2008). How to teach thinking skills in social studies and history. The Social Studies, 99(5), 196-201. http://dx.doi.org/10.3200/TSSS.99.5.196-201

Bilir, A. (2011). Historical evolution of teacher training and staffing policies in Turkey. Ankara University Journal of Faculty of Educational Sciences, 44(2), 223-246.

Blanco, F., \& Rosa, A. (1997). Dilthey's dream. Teaching history to understand the future. International Journal of Educational Research, 27(3), 189-200. http://dx.doi.org/10.1016/S0883-0355(97)89727-3

Brown, S. D. (2013). Preparing effective history teachers: The assessment gap. Journal of Social Studies Research, 37(3), 167-177. http://dx.doi.org/10.1016/j.jssr.2013.04.005

Cave, P. (2002). Teaching the history of empire in Japan and England. International Journal of Educational Research, 37(6-7), 623-641. http://dx.doi.org/10.1016/S0883-0355(03)00054-5

Clark, A. (2006). Teaching the Nation. Victoria: Melbourne University Press.

Clark, A. (2009). Teaching the nation's story: comparing public debates and classroom perspectives on history education in Australia and Canada. Journal of Curriculum Studies, 41(6), 745-762. http://dx.doi.org/10.1080/00220270903139635

Cohen, L., Manion, L., \& Morrison, K. (2012). Research methods in education. Professional Development in Education (6th ed., Vol. 38). New York: Routledge. http://dx.doi.org/10.1080/19415257.2011.643130

Demircioğlu, İ. H. (2006). High school students' views regarding history teaching. Journal of Turkish Educational Sciences, 4(2), 32-44.

Deringöl, Y. (2007). An investigation into class teacher training in Turkey since the establishment of Republic and educators' views related. Journal of Hasan Ali Yücel Education Faculty, 2, 17-27.

Dinç, E. (2006). Educators' views regarding current history curriculum and history teaching objectives. Journal of Ahi Evran University Kirsehir Education Faculty, 7(2), 263-276.

Durkheim, É. (1922). Éducation et sociologie. Paris: Libraire Félix Alcan. Retrieved from http://gallica.bnf.fr/ark:/12148/bpt6k813131.r=Durkheim,+Émile.langEN

Fullan, M. (2007). The new meaning of educational change (4th ed.). New York: Teacher Ideas Press. http://dx.doi.org/10.1007/s10833-006-9003-9

Gerwin, D., \& Visone, F. (2006). The Freedom to teach: Contrasting History teaching in elective and state-tested courses. Theory \& Research in Social Education, 34(2), 259-282. 
http://dx.doi.org/10.1080/00933104.2006.10473307

Gutiérrez, V., Ricardo, G., \& Segura, I. (2015). Ensino de "Temas Polémicos" no Curso de historia, a partir da perspectiva dos estudantes Chilenos. Revista de Estudios Sociales, 2(52), 119-133. http://dx.doi.org/10.7440/res52.2015.08

Güven, A. (2002). Democratic citizenship and history teaching. Journal of Atatürk University Journal of Social Sciences Institute, 12(2), 337-350.

Harris, L. M., \& Bain, R. B. (2010). Pedagogical content knowledge for world history teachers: What is it? How Might prospective teachers develop it? The Social Studies, 102(1), 9-17. http://dx.doi.org/10.1080/00377996.2011.532724

Haynes, B. (2009). History teaching for patriotic citizenship in Australia. Educational Philosophy and Theory, 4l(4), 424-440. http://dx.doi.org/10.1111/j.1469-5812.2008.00430.x

James, J. H. (2008). Teachers as protectors: Making sense of preservice teachers' resistance to interpretation in elementary history teaching. Theory \& Research in Social Education, 36(3), 172-205. http://dx.doi.org/10.1080/00933104.2008.10473372

Jones, A. (2002). Politics and history curriculum reform in post-Mao China. International Journal of Educational Research, 37(6-7), 545-566. http://dx.doi.org/10.1016/S0883-0355(03)00050-8

Kahveci, N. G. (2007). Teaching "Europe" in Turkey: An Analysis of Secondary History Textbooks 1956-2005. (Unpublished doctoral dissertaion). University of Illinois. Retrieved June 3, 2015, from http://search.proquest.com/pqdtglobal/docview/304858187/66B95D256051408FPQ/4?accountid=15329

Kavcar, C. (2002). Branch teacher education in Republic Period. Ankara University Journal of Faculty of Educational Sciences, 35(1-2), 1-14.

Kaya, R., Aslan, H., \& Günal, H. (2013). An investigation into history teacher candidates' reasons to choose the department and their expectations (Atatürk University Case). Jounal of Turkish History Teaching, 2(2), 1-31.

Kello, K., \& Wagner, W. (2014). Intrinsic and extrinsic patriotism in school: Teaching history after Estonia's critical juncture. International Journal of Intercultural Relations, $43,48-59$. http://dx.doi.org/10.1016/j.ijintrel.2014.08.016

Klein, S. R. E. (2010). Teaching history in the Netherlands: Teachers' experiences of a plurality of perspectives. Curriculum Inquiry, 40(5), 614-634. http://dx.doi.org/10.1111/j.1467-873X.2010.00514.x

Korostelina, K. (2013). Constructing nation: national narratives of history teachers in Ukraine. National Identities, 15(4), 401-416. http://dx.doi.org/10.1080/14608944.2013.843515

Köken, N. (2002). History perceptions in republic period and history teaching (1923-1960). (Unpublished doctoral dissertation). Süleyman Demirel University, İsparta.

Magendzo, A., \& Toledo, M. I. (2009). Moral dilemmas in teaching recent history related to the violation of human rights in Chile. Journal of Moral Education, 38(4), 445-465. http://dx.doi.org/10.1080/03057240903321923

Martell, C. C. (2013). Learning to teach history as interpretation: A longitudinal study of beginning teachers. Journal of Social Studies Research, 37(1), 17-31. http://dx.doi.org/10.1016/j.jssr.2012.12.001

Martell, C. C. (2014). Building a constructivist practice: A longitudinal study of beginning history teachers. The Teacher Educator, 49(2), 97-115. http://dx.doi.org/10.1080/08878730.2014.888252

Nichol, J., \& Dean, J. (2005). History 7-11 Developing primary teaching skills. London: Routledge.

Nurdoğan, A. M. (2014). Textbooks and history teaching at primary school during Abdulhamid II. period. Journal of Turkish History Teaching, 3(2), 82-111.

Nye, A., Hughes-Warrington, M., Roe, J., Russell, P., Deacon, D., \& Kiem, P. (2011). Exploring historical thinking and agency with undergraduate history students. Studies in Higher Education, 36(7), 763-780. http://dx.doi.org/10.1080/03075071003759045

Osborne, K. (2003). Teaching history in schools: A Canadian debate. Journal of Curriculum Studies, 35. http://dx.doi.org/10.1080/0022027032000063544

Özoğlu, M. (2010). Challenges in teacher training system in Turkey. Foundation for Political, Economical and Social Researches.

Phillips, R., Goalen, P., McCully, A., \& Wood, S. (1999). Four histories, one nation? History teaching, nationhood and a 
British identity. Compare: A Journal of Comparative and International Education, 29(2), 153-169. http://dx.doi.org/10.1080/0305792990290205

Philpott, J. (2011). Assessment. In I. Davis (Ed.), Debates in history teaching (pp. 261-272). New York: Routledge. http://dx.doi.org/10.1080/19415257.2012.717735

Reitano, P., \& Green, N. C. (2013). Beginning teachers' conceptual understandings of effective history teaching: examining the change from "subject knowers" to "subject teachers." Asia-Pacific Journal of Teacher Education, 4l(2), 197-217. http://dx.doi.org/10.1080/1359866X.2013.777027

Safran, M. (2002). Turkish history teaching and the challenges. In Türkler Encyclopedia. Yeni Türkiye Publication. http://www.tarihtarih.com/?Syf=26\&Syz=355456 Turk

Safran, M., Ata, B., Türkan, F., Gümüşlü, B., \& Cansever, Ü. (2011). History teaching efficiency domains. http://otmg.meb.gov.tr/alan_tarih_ortaogretim.html

Swartz, A. D. (1997). Textbooks and national ideology: A Content analysis of the secondary Turkish history textbook used in the Republic of Turkey since 1929. Austin: University of Texas. http://dx.doi.org/10.16953/deusbed.74839

Ünişen, A. (2013). II. An evaluation of the articles on educational sciences in journal published in Istanbul during the $2^{\text {nd }}$ Constitutional Period (Unpublished doctoral dissertation). Gaziantep University, Gaziantep, Turkey.

Veccia, S. H. (2004). Uncovering Our history: Teaching with primary sources. Chicago: American Library Association.

Vickers, E. (2005). In Search of an identity: The politics of history as a school subject in Hong Kong, 1960s-2002. New York: Routledge.

Virta, A. (2002). Becoming a history teacher: Observations on the beliefs and growth of student teachers. Teaching and Teacher Education, 18(6), 687-698. http://dx.doi.org/10.1016/S0742-051X(02)00028-8

Vural, F. (2014). Teacher training in Turkey and pedagogical formation problem. Journal of Teacher Education and Educators, 3(1), 73-90.

Wiersma, A. (2008). A study of the teaching methods of high school history teachers. The Social Studies, 99(3), 111116. http://dx.doi.org/10.3200/TSSS.99.3.111-116

Yllmaz, K. (2008). A vision of history teaching and learning: thoughts on history education in secondary schools. The High School Journal, 92(2), 37-46. http://dx.doi.org/10.1353/hsj.0.0017

Yllmaz, S. (2007). New European identity creation through history teaching and Turkey's adaptation to it. Academic Reviews, 2(1), 69-95.

Yin, R. K. (2012). Qualitative research from start to finish. New York: Guilford Press.

Zembylas, M., \& Kambani, F. (2012). The teaching of controversial issues during elementary-level history instruction: greek-cypriot teachers' perceptions and emotions. Theory \& Research in Social Education, 40(2), 107-133. http://dx.doi.org/10.1080/00933104.2012.670591

\section{(c) EY}

This work is licensed under a Creative Commons Attribution 3.0 License. 